\title{
GAMBARAN TINGKAT PENDIDIKAN, STATUS EKONOMI SERTA BUDAYA PELAKU PERNIKAHAN DINI DI WILAYAH KELURAHAN LINGGASARI KECAMATAN CIAMIS KABUPATEN CIAMIS TAHUN 2013 OLEH : \\ DADAN YOGASWARA, S.KM, M.KM
}

\section{A. ABSTRAK}

Berdasarkan hasil survei data yang di peroleh dari Departemen Agama Ciamis tahun 2012 jumlah perempuan yang menikah 913 orang. Dari study pendahuluan tersebut dapat dilihat bahwa ibu yang menikah di usia kurang dari 20 tahun yaitu 126 orang. Dan dari data yang di dapat dari Kecamatan Ciamis wanita yang menikah di usia kurang dari 20 tahun sebanyak 32 orang dan hasil terbanyak terdapat di Kelurahan Linggasari tahun 2012 dengan jumlah 28 orang. Tujuan dari penelitian ini adalah mengetahui faktor pendidikan, status ekonomi serta budaya pelaku pernikahan dini di wilayah Kelurahan Linggasari Kecamatan Ciamis tahun 2013.

Jenis penelitian yang digunakan adalah kuantitatif dengan metode deskriptif. Populasi dalam penelitian ini adalah pelaku pernikahan dini pada tahun 2012 yaitu 41 orang. Tehnik pengambilan sampel dalam penelitian ini adalah total sampling dimana seluruh populasi dijadikan sampel dalam penelitian. Variabel dalam penelitian ini adalah tingkat pendidikan, status ekonomi serta budaya. Instrumen dalam penelitian ini menggunakan lembar isian. Analisis data dalam penelitian ini adalah analisis univariat. Analisis ini menghasilkan distribusi frekuensi untuk menggambarkan tiap-tiap variabel yang akan diteliti.

Berdasarkan hasil penelitian didapatkan bahwa mayoritas tingkat pendidikan pelaku pernikahan dini di Kelurahan Linggarsari Tahun 2013 adalah tingkat pendidikan rendah yaitu $78.04 \%$, tingkat sosial ekonomi pelaku pernikahan dini di Kelurahan Linggarsari Tahun 2013 adalah ekonomi rendah yaitu 60.97\%. serta mayoritas budaya pelaku pernikahan dini di Kelurahan Linggarsari Tahun 2013 adalah mempercayai mitos yang berkembang di masyarakat tentang pernikahan dini yaitu $87.8 \%$.

Saran bagi remaja diharapkan lebih meingkatkan pengetahuan dan wawasan melalui pencarian informasi tentang resiko pernikahan dini. sedangkan bagi petugas kesehatan dapat bekerjsama dengan tokoh agama dalam upaya pencegahan pernikahan usia dini melalui berbagai kegiatan seperti penyuluhan bagi remaja.

Kata Kunci : Pernikahan dini, tingkat pendidikan, sosial ekonomi dan budaya 


\section{B. PENDAHULUAN}

Berdasarkan UU Perlindungan Anak No. 23 Tahun 2012, pernikahan dini adalah mereka yang menikah sebelum berusia delapan belas tahun. Berdasarkan data Riset Kesehatan Dasar tahun 2010 menunjukkan, angka pernikahan usia dini di bawah usia 19 tahun, sebesar 46,7 persen. Di samping itu, Indonesia menempati urutan ke-37 di di antara negaranegara yang memiliki jumlah pernikahan usia dini tertinggi di dunia (World Fertility Policies, United Nations, 2011).

Organisasai kesehatan dunia (WHO) tahun 2012 menunjukkan bahwa sebanyak 16 juta kelahiran terjadi pada ibu yang berusia 15-19 tahun atau $11 \%$ dari seluruh kelahiran didunia yang mayoritas $(95 \%)$ terjadi dinegara sedang berkembang. Di Amerika Lati dan Karibia, 29\% wanita muda menikah saat mereka berusia 18 tahun. Prevalensi tertinggi kasus pernikahan usia dini tercatat di Nigeria (80\%), Kongo (74\%), Afganistan (54\%), dan Bangladesh (51\%) (WHO, 2012).

Sedangkan berdasarkan SDKI tahun 2012 tercatat 4,8\% menikah di usia 20-24 tahun dan 41,9\% menikah pada usia 15-19 tahun atau 41 per 1000 pernikahan. Dari data tersebut, dapat dilihat besarnya angka pernikahan dini di Indonesia. Menurut Taufik (2008) dalam Damayanti (2012), angka statistik pernikahan dengan pengantin wanita berusia dibawah 16 tahun secara keseluruhan mencapai lebih dari seperempat dari total pernikahan di Indonesia. Bahkan di beberapa tempat, angkanya jauh lebih besar, misalnya di Jawa Timur 39,43\%,

Menurut BKKBN (2011) faktor yang mempengaruhi rata-rata usia menikah pertama perempuan adalah faktor social, ekonomi, budaya dan tempat tinggal (desa/kota). Beberapa ahli menyatakan bahwa pernikahan dini sering disebabkan oleh faktor ekonomi, pendidikan, faktor diri sendiri dan faktor orang tua (Puspitasari, 2009).

Rendahnya tingkat ekonomi keluarga mendorong si anak untuk menikah di usia yang tergolong muda. Orang tua beranggapan bahwa anaknya menikah bisa mengurangi beban ekonomi keluarga dan calon suami si anaknya bisa membantu perekonomian keluarga. Faktor kemauan sendiri bisa disebabkan karena keduanya merasa sudah saling mencintai dan adanya pengetahuan anak yang diperoleh dari film atau media-media yang lain sehingga mereka terpengaruh untuk melakukan seks sebelum menikah dan terjadi kehamilan diluar nikah dimana remaja terpengaruh untuk melakukan pernikahan dini. Orang tua/keluarga biasanya juga menyuruh anaknya menikah secepatnya padahal umur mereka belum matang untuk melangsungkan pernikahan karena sudah turun-menurun. (Mencher Siagian, 2012).

Berdasarkan hasil survei data yang di peroleh dari Departemen Agama Ciamis tahun 2012 jumlah perempuan yang menikah 913 orang. Dari study pendahuluan tersebut dapat dilihat bahwa ibu yang menikah di usia kurang dari 20 tahun yaitu 126 orang. Dan dari data yang di dapat dari Kecamatan Ciamis wanita yang menikah di usia kurang dari 20 tahun sebanyak 32 orang dan hasil terbanyak terdapat di Kelurahan Linggasari tahun 2012 dengan jumlah 28 orang.

Berdasarkan data tersebut penulis bermaksud untuk melakukan penelitian dengan judul " Gambaran tingkat pendidikan, status ekonomi serta budaya pelaku pernikahan dini di wilayah Kelurahan Linggasari 
Kecamatan Ciamis Kabupaten Ciamis Tahun 2013.

Tujuan dari penelitian ini adalah mengetahui faktor pendidikan, status ekonomi serta budaya pelaku pernikahan dini di wilayah Kelurahan Linggasari Kecamatan Ciamis tahun 2013.

\section{METODOLOGI PENELITI}

1. Jenis penelitian

Jenis penelitian yang digunakan adalah kuantitatif dengan metode deskriptif.

2. Populasi dan sampel

Populasi dalam penelitian ini adalah pelaku pernikahan dini pada tahun 2012 yaitu 41 orang. Tehnik pengambilan sampel dalam penelitian ini adalah total sampling dimana seluruh populasi dijadikan sampel dalam penelitian.

3. Waktu dan tempat penelitian

Waktu penelitian adalah bulan Mei - Juni 2014

Tempat penelitian : Kelurahan Linggasari Kecamatan Ciamis

4. Variabel

Variabel dalam penelitian ini adalah tingkat pendidikan, status ekonomi serta budaya.

5. Instrumen penelitian

Instrumen dalam penelitian ini menggunakan lembar isian.

6. Pengolahan data

Pengolahan data penelitian dilakukan dengan cara :

a. Editing

Tahapan ini dilakukan dengan cara mengecek kelengkapan kebutuhan data penelitian.

b. Coding

Pemberian kode untuk setiap pilihan jawaban seperti :

1. Untuk variabel tingkat pendidik : Kode 1 Tamat SD, kode 2 Tamat SMP, Kode 3 Tamat SMA, serta kode 4 Tamat PT.
2. Untuk variabel sosial ekonomi : Kode 1 diatas UMR, kode 2 untuk dibawah UMR.

3. Untuk budaya kode $1:$ Ya dan kode 2 : tidak

c. Entry data

Proses memasukan data ke program komputerisasi untuk disajikan dalam bentuk tabel dan dianalisis secara narasi

7. Analisis data

Analisis data dalam penelitian ini adalah analisis univariat. Analisis ini menghasilkan distribusi frekuensi untuk menggambarkan tiap-tiap variabel yang akan diteliti.

D. HASIL PENELITIAN

1. Gambaran tingkat pendidikan pelaku pernikahan dini

Tabel 4.1

Distribusi Frekwensi Tingkat Pendidikan Pelaku Pernikahan Dini Di Kelurahan Linggasari Kecamatan Ciamis Tahun 2013

\begin{tabular}{|l|l|c|c|}
\hline No & $\begin{array}{l}\text { Tingkat } \\
\text { pendidikan }\end{array}$ & F & \% \\
\hline 1 & Dasar & 32 & 78.04 \\
\hline 2 & Menengah & 5 & 12.19 \\
\hline 3 & Tinggi & 4 & 9.75 \\
\hline & Jumlah & $\mathbf{4 1}$ & $\mathbf{1 0 0}$ \\
\hline
\end{tabular}

Berdasarkan tabel 4.1 didapatkan bahwa mayoritas tingkat pendidikan pelaku pernikahan dini adalah tingkat pendidikan rendah yaitu $78.04 \%$. 
2. Gambaran sosial ekonomi pelaku pernikahan dini

Tabel 4.2

Distribusi Frekwensi Tingkat Sosial Ekonomi

Pelaku Pernikahan Dini Di Kelurahan Linggasari Kecamatan Ciamis Tahun 2013

\begin{tabular}{|c|l|c|c|}
\hline No & $\begin{array}{l}\text { Sosial } \\
\text { ekonomi }\end{array}$ & F & \% \\
\hline 1 & Rendah & 25 & 60.97 \\
\hline 2 & Menengah & 12 & 29.26 \\
\hline 3 & Tinggi & 4 & 9.75 \\
\hline & Jumlah & $\mathbf{4 1}$ & $\mathbf{1 0 0}$ \\
\hline
\end{tabular}

Berdasarkan tabel 4.2 didapatkan bahwa mayoritas tingkat sosial ekonomi pelaku pernikahan dini adalah ekonomi rendah yaitu $60.97 \%$.

\section{Gambaran budaya pernikahan dini}

Tabel 4.3

Distribusi Frekwensi Budaya Pelaku Pernikahan Dini

\begin{tabular}{|l|l|c|c|}
\hline No & Budaya & F & \% \\
\hline 1 & Percaya & 36 & 87.8 \\
\hline 2 & Tidak percaya & 5 & 19.5 \\
\hline & Jumlah & $\mathbf{4 1}$ & $\mathbf{1 0 0}$ \\
\hline
\end{tabular}

Berdasarkan tabel 4.3 didapatkan bahwa mayoritas budaya pelaku pernikahan dini adalah mempercayai mitos yang berkembang di masyarakat tentang pernikahan dini yaitu $87.8 \%$.

\section{E. PEMBAHASAN}

\section{Tingkat pendidikan dan pernikahan dini}

Berdasarkan

hasil

penelitian didapatkan bahwa mayoritas tingkat pendidikan pelaku pernikahan dini adalah tingkat pendidikan rendah yaitu $78.04 \%$.
Implikasi pendidikan yang berdasarkan pendapat Freud: "Pendidikan adalah suatu untuk memperhalus dan membudayakan dorongandorongan kelamin sesuai dengan harapan masyarakat". Memperdalam ilmu dalam dunia pendidikan seringkali membuat orang melupakan kehidupan pribadinya. Seseorang tidak memikirkan kebutuhan biologisnya dikarenakan kesibukan yang mengisi kesehariannya.

Tingkat pendidikan yang tinggi akan memberikan pemahaman secara matang kepada individu untuk memilih atau memutuskan suatu hal. Individu tersebut tidak menginginkan jika hal yang buruk yang tidak diinginkan menimpa dirinya akibat dari keputusan yang telah diambil olehnya. Kalau pernikahan dilakukan di bawah 20 tahun, maka secara emosi remaja masih ingin berpetualang menemukan jati dirinya.

Kurangnya pendidikan bisa dikarenakan faktor ekonomi, dari faktor ekonomi inilah seseorang tidak mampu melanjutkan pendidikan dan juga dikarenakan oleh keluarga yang relative besar. Selain itu faktor sosial budaya juga mempengaruhi kurangnya pendidikan, mungkin pendidikan masyarakat di lingkungan sekitar yang tergolong rendah menyebabakan para remaja malas melanjutkan pendidikan ke jenjang lebih tinggi.

Tingkat pendidikan maupun pengetahuan anak yang rendah dapat menyebabkan adanya kecenderungan melakukan pernikahan di usia 
dini. Sehingga peran pendidikan dalam hal ini sangat penting dalam mengambil keputusan individu (Alfiyah 2010). Sedangkan menurut Notoatmojo

mengungkapkan bahwa semakin tinggi pendidikan maka akan semakin besar pengetahuan yang didapatkan. Remaja yang berlatarbelakang pendidikan tinggi memiliki resiko lebih kecil untuk melakukan penikahan dini dibandingkan responden yang berlatarbelakang pendidikan rendah. Hal ini dikarenakan pengetahuan yang merekadapatkan lebih banyak.

\section{Tingkat sosial ekonomi dan pernikahan dini}

Berdasarkan tabel 4.2 didapatkan bahwa mayoritas tingkat sosial ekonomi pelaku pernikahan dini adalah ekonomi rendah yaitu $60.97 \%$.

Menurut peneliti remaja putri yang tinggal di dalam keluarga dengan status ekonomi rendah dengan indikator pendapatan keluarga/bulan di bawah UMK maka orang tua akan mendorong remaja putri agar segera menikah untuk meringankan beban keluarga, karena setelah menikah akan menjadi tangggung jawab suami. Selain itu remaja putri yang tinggal di keluarga dengan status ekonomi rendah tidak memiliki alternatif pilihan melanjutkan sekolah ke jenjang pendidikan yang lebih tinggi karena tidak mampu membayar biaya yang ditentukan oleh sekolah.

Begitupun sebaliknya remaja putri yang tinggal di lingkungan keluarga dengan status ekonomi keluarga tinggi maka orang tua mampu secara finansial untuk menanggung biaya hidup remaja dan memiliki pandangan yang lebih baik agar remaja lebih fokus untuk menyelesaikan pendidikan terlebih dahulu daripada menikah. Selain itu remaja yang tinggal di dalam keluarga dengan status ekonomi tinggi juga mampu untuk mengakses informasi yang didapat dari sumber belajar baikmedia cetak maupun elektronik tentang dampak jika menikah dini, sehingga ada proses transfer informasi yang dapat menambah pengetahuan remaja putri sehingga dapat diaplikasikan ke dalam tindakan untuk tidak menikah dini.

Hal ini sejalan dengan norma yang berkembang di lapangan bahwa terdapat nilai yang berkembang bahwa anak perempuan merupakan aset ekonomi keluarga, dimana anak perempuan diharapkan dapat mengangkat derajat ekonomi keluarga. Salah satu diantaranya adalah dengan menikah diusia dini. Hasil analisis ini sejalan dengan penelitian sebelumnya yang dilakukan oleh Landung dkk (2009) yang menemukan bahwa adanya keinginan pada remaja untuk dapat membantu perekonomian keluarga. Keadaan ekonomi keluarga yang rendah mendorong remaja untuk berkeinginan bekerja di luar negeri. Keinginan tersebut berkaitan dengan keinginan segera menikah. Mayoritas remaja putri yang bekerja di luar negeri melakukan pernikahan terlebih dahulu sebelum berangkat pergi bekerja. Hal tersebut dilakukan dengan maksud untuk memberikan rasa aman dan menghindari omongan 
buruk masyarakat atas pekerjaan di luar negeri. Pada masyarakat juga berkembang anggapan bahwa perempuan yang bekerja di luar negeri selain bekerja sebagai Pembantu Rumah Tangga (PRT).

\section{Budaya dan pernikahan dini}

Berdasarkan tabel 4.3 didapatkan bahwa mayoritas budaya pelaku pernikahan dini adalah mempercayai mitos yang berkembang di masyarakat tentang pernikahan dini yaitu $87.8 \%$.

Dari berbagai determinan perilaku manusia, banyak ahli telah merumuskan teori-teori atau model-model terbentuknya perilaku, begitu pula dengan perilaku pernikahan dini pada remaja. Berdasarkan pengalaman empiris di lapangan, perilaku pernikahan dini dapat dilihat dari tiga aspek yaitu aspek fisik, psikis, dan sosial. Akan tetapi dari ketiga aspek tersebut sulit untuk ditarik garis yang tegas dalam mempengaruhi perilaku khususnya pernikahan dini Perilaku manusia sebenarnya merupakan refleksi dari berbagai gejala kejiwaan, seperti pengetahuan, keinginan, kehendak, minat, motivasi, persepsi, sikap, dan sebagainya.

Budaya yang berkembang di masyarakat tentang pernikahan dini yaitu wanita tak boleh sampai terlambat menikah, atau mempunyai alasan jika dinikahkandengan orang yang sudah berada, tak perlu khawatir masa depannya akan terpuruk. Oleh karena itu banyak anakanak usia remaja pun sudah dinikahkan. Bahkan ada budaya perjodohan sejak anak perempuan belum lulus SD atau masih SMP. Namun, alasan budaya tidak semata-mata sebagai alasan utama keluarga menikahkan anak perempuannya saat masih belia (Lubis, 2012).

Anak perempuan

kebanyakan diperintahkan untuk segera menikah oleh orangtuanya, alasan yang melatar belakangi adalah mematuhi hukum adat-istiadat yang ada sejak jaman nenek moyang dan anjuran agama. Hal tersebut dikarenakan kekhawatiran orang tua agar anak perempuannya tersebut selamat dari mitos perawan tua.

\section{F. SIMPULAN DAN SARAN}

1. Simpulan

a. Mayoritas tingkat pendidikan pelaku pernikahan dini di Kelurahan Linggarsari Tahun 2013 adalah tingkat pendidikan rendah yaitu $78.04 \%$.

b. Mayoritas tingkat sosial ekonomi pelaku pernikahan dini di Kelurahan Linggarsari Tahun 2013 adalah ekonomi rendah yaitu $60.97 \%$.

c. Mayoritas budaya pelaku pernikahan dini di Kelurahan Linggarsari Tahun 2013 adalah mempercayai mitos yang berkembang di masyarakat tentang pernikahan dini yaitu $87.8 \%$.

2. Saran

a. Remaja

Remaja diharapkan lebih meingkatkan pengetahuan dan wawasan melalui pencarian informasi tentang resiko pernikahan dini. 
b. Petugas kesehatan

Petugas kesehatan dapat bekerjsama dengan tokoh agama dalam upaya pencegahan pernikahan usia dini melalui berbagai kegiatan seperti penyuluhan bagi remaja.

\section{G. DAFTAR PUSTAKA}

Widianti E. (2007). Remaja dan permasalahannya: bahaya merokok, penyimpangan seks pada remaja, dan bahaya penyalahgunaan minuman keras/narkoba. Fakultas Ilmu Keperawatan Universitas Padjadjaran. Hurlock EB.

Soedjarwo, Istiwidayanti. (2009). Psikologi Perkembangan Suatu Pendekatan Sepanjang Rentang
Kehidupan. Jakarta: Penerbit Erlangga

KUA Ciamis. (2012) Data Pernikahan Dini di KUA. Ciamis.

Notomoatmodjo, S. (2007). Metodologi Penelitian Kesehatan, Rineka Cipta, Jakarta.

UU Perlindungan Anak No. 23 tahun 2002.

Undang-undang Nomor 20 Tahun 2003, tentang Sistem Pendidikan Nasional.

Wikipedia Berbahasa Indonesia, Ensiklopedia Bebas "Pernikahan Dini". http://tydar.blogspot.com/2012/01/ma kalah-pernikahan-dini.html

Janiwarty dan Pieter, 2012. Pendidikan psikologi untuk bidan: suatu teori dan terapannya. Yogyakarta: Andi Offset 